$\xi^{2}=1$ 줄

\title{
GIS based mapping and analysis of landslide hazard's impact on tourism: a case study of Balakot valley, Pakistan
}

\author{
Alamgeer Hussain*, Mobushir Riaz Khan, Naeem Abbas Malik, Muhammad Amin, \\ Mazhar Hussain Shah, Muhammad Naveed Tahir \\ Institutes of Geo-Information \& Earth Observation, Pir Mehr Ali Shah Arid Agriculture University, Rawalpindi, Pakistan \\ *Corresponding author E-mail: alamgeerh@gmail.com
}

\begin{abstract}
The Landslide occurs in mountainous area due to failure of slope through intensive rain and earthquake. Region wise Himalayan is one of prone area of world in context of slope failure hazard; i.e. Landslide, especially Balakot valley is well known for damage of public infrastructure, roads and badly affected the tourism sector. The objective of this study is to develop landslide hazard map and database inventory of balakot tehsil and identify the Tourist resorts landslide hazard condition and hazard prone road site and developed guidelines for tourist about hazardous site and their intensity of landside, which could be useful for tourism sector and sustainable development in balakot valley. In this study we used weighted overlay analysis in arc GIS environment on primary and secondary data raster layers, like slope map, Slope Aspect map, precipitation and seismic raster maps were used to develop landslide hazard zonation map of balakot tehsil. Slope and Aspect map were developed using 30 meter aster digital elevation model. Precipitation map were developed through Inverse Distance weighted (IDW) interpolation method on annual precipitation data acquired from Pakistan meteorological department. Seismic map were acquired from Geological Survey of Pakistan (GSP). Landslide zonation map has three hazards class high, Medium and low. The landslide exposure of high hazard class 499 sq.km while, Medium class 1016 sq.km and low hazard class having 749 sq. km exposure in balakot tehsil respectively. Landslide hazard zonation mapping using GIS and RS is the best way to assess the risk of landslide hazard in mountainous areas. The study recommended that ground penetrating radar (GPR) and soil testing based research well help to understand in-depth of landslide hazard condition in balakot valley.
\end{abstract}

Keywords: GIS; RS; GPR; GSP; Slope; Slope Aspect.

\section{Introduction}

This document Landslides are one of the most widespread disasters that cause serious losses to various aspects of life. The term "Landslide" includes all types of mass movement down a slope which can consist of soil, rock, debris, organic matter, artificial fill, or a combination of these. The downward or outward movements can be classified in different groups based on the velocity of motion $(\mathrm{mm} /$ year to tens of $\mathrm{m} / \mathrm{s})$, the water content of the materials, for example, and other characteristics. Picarelli, L. at al (2014) has presented a comprehensive categorization of landslide process that includes falling, toppling, sliding, spreading, and flowing, all of which constitute conditions of causal effects and slope characteristics.

Various impacts of landslides have increased in past decades due to the rapid growth of urbanization in Pakistan. Landslide effects especially in Balakot valley have damaged many aspects of human life and the natural environment, and many difficulties remain for accurate assessments and evaluations. The lack of systematic studies on Landslide impacts have resulted a limited view on the future consequences, so detailed investigations are required to achieve a comprehensive view of landslide impacts on social and environmental life in Pakistan.

In the last years, natural extreme events have caused substantial damage to tourism destinations in Balakot valley.Apart from inundations, primarily mass movements such as falling rocks, landslides, debris flows or avalanches are of importance along
Balakot- Naran road. Such events have not only caused substantial direct damage to tourism infrastructures, but also indirectly led to significant decreases of tourists and therefore to considerable deficiencies in receipts.

Atleast as a result of an expected increase of certain extreme events in relation to climate change, public awareness of the topic has risen significantly. The enhanced cross-linking of the economy and growing safety requirements have led to a higher vulnerability. From a tourism point of view, its strong exposure and the expansion of tourism infrastructures on the one hand and increasing activities of tourists in hazardous areas on the other hand resulted in a higher risk for accidents and damages to lives and property of the tourists. The research study in hand aims to map and examine the impacts of landslides hazard on tourism in Balakot valley. Geographic Information System and Remote sensing (GIS/RS) provide a powerful procedure by demonstrating the landslides hazard for their spatial analysis and future occurrence (Carrara et al. 1991, Drabek 1994) and Cater (2006). This is because of the fact that GIS has the capabilities to spatially analyze the landslides hazard and vulnerability.Landslides distribution and factors that contribute to slope instabilities are explored by using statistical analysis as well as a map of landslides susceptibility in GIS that is illustrating the high and low susceptibility regions. Obviously analysis of landslide risk is extremely helpful in risk management, Wang, Y. at al. (2013). Balakot Valley is situated in District Mansehra. Mansehra district was established on 1st October 1976. The beautiful valleys of 
Mansehra before its declaration as district in 1976 were a tehsil of Hazara district. After the 1981 census of Pakistan it was bifurcated in to Mansehra and Batagram districts. In $997 \mathrm{CE}$, Sultan Mahmud Ghaznavi, took over the Ghaznavid dynasty empire established by his father, Sultan Sebuktegin, In 1005 he conquered the Shahis in Kabul in 1005, and followed it by the conquests of Khyber-Pakhtunkhwa.

As per historical aspects of Balakot valley, after the decline of the Mughal Empire, the Sikhs invaded and occupied Mandi Bahauddin District. Bhangi Misl was the first of many Sikh bands to invade and plunder the Mughal Lahore and other cities in Punjab. Many visitors to Lahore during this era noted that much of the city was in disrepair and many of its Muslim monuments and Mosques were pillaged and desecrated by the Sikhs Ali, I., Shah. et al(2013). The land, palaces and houses of Muslim nobility were confiscated by the Sikhs Sardars. Marbles and precious stones were pillaged from Muslim buildings, including Shalimar Gardens, and homes by the Sikhs to build Golden Temple in Amritsar and the other Sikh holy places. Syed Ahmad Barelvi a Muslim nationalist received desperate pleas of help from the persecuted Muslims of the Punjab region. The Muslims were prohibited to call Azan and lands belonging to the waqf endowments which provided financial support to Muslim institutions were confiscated by the Sikhs. Syed Ahmad Barelvi in 1821 with many supporters and spent twoyears organizing popular and material support for his Punjab campaign. He carefully developed a network of people through the length and breadth of India to collect funds and encourage volunteers, traveling widely throughout India attracting a following among pious Muslims. In December 1826 Sayyid Ahmad and his followers clashed with Sikh troops at Akora but with no decisive result. In a major battle near the town of Balakot in 1831, Sayyid Ahmad and Shah Ismail Shaheed with volunteer Muslims were defeated and martyred by the professional Sikh Army. The Muslims faced severe restrictions during the Sikh rule, Schickhoff, U. (1995).

The Balakot town was completely destroyed in the massive earthquake on 8 October 2005. The fault line almost passes through the main bazar of Balakot. It follows the hilly area to the north up to Allai and leads to the Bagh in Azad Jammu \& Kashmir from the villages of Balakot like Kanshian and Jabri Kaleesh. The United Arab Emirates has volunteered to rebuild this town into an improved one with housing colonies, schools, hospitals, and other civic facilities. However the Pakistan government has announced that the city will be relocated. The town will be reconstructed about $20 \mathrm{~km}$ away at a safer spot with more earthquake-proof buildings. The hillside town of Balakot, comprising 12 union councils with a population of 30,000 people, was completely destroyed by the earthquake on 8 October 2005 . Over 90 per cent of the houses were reduced to muddy smears. The survivors will be relocated to the New Balakot City, currently being developed near Mansehra.

The 08 October 2005, earthquake occurred along the BalakotBagh fault (BBF) with about $30^{\circ}$ dip toward NE in the internal part of the western Himalayas in north Pakistan. It was accompanied by a ground rupture of about $75 \mathrm{~km}$ with an average slip of about $5 \mathrm{~m}$ along the causative fault. The epicenter of the thrust was located at about $19 \mathrm{~km}$ to the NE of its surface trace in Muzaffarabad with about $11 \mathrm{~km}$ depth of the hypocenter. The geometry of the fault based on a structural cross section has allowed us to interpret it as a thrust restricted to a roof sequence along a triangle zone across the Hazara-Kashmir syntaxis (HKS). The triangle zone is occupied at depth by a wedge of the Higher Himalayan Sequence (HHS) in the core zone of the HKS. The core-wedge is bounded between the NE-dipping BBF and SE- to SW-dipping thrust stack of the Lesser Himalayan Sequence (LHS) along the northeastern and southwestern limb of the HKS respectively. Based on surface geology, the overlapping BBF and MBT are interpreted to merge at depth in a roof thrust of PreCambrian (Late Proterozoic) rocks above a duplex which is inferred to have a floor thrust in Early Proterozoic/Archean rocks. The core-wedge is located over a ramp which is connected to the floor thrust in the basement. The BBF is inferred to be active, at least since 1-0.5 Ma, with recurrence interval of about $625 \pm 125$ years. This out-of-sequence deformation is represented by linear seismicity, both along emergent and blind thrusts in the system, with likelihood of major events as a result of strain buildup due to slow convergence rates $(\sim 7 \mathrm{~mm} /$ year) in the region. Many towns located along the active fault trace were destroyed or largely damaged due to the earthquake. Major destruction of human dwellings and infrastructure occurred as a consequence of earthquake-triggered landslides, mostly along fault, high river terraces, and road cuts.To minimize future damages in earthquakeprone areas, several mitigation measures are suggested including: (1) avoiding new settlements near the fault trace and landslide susceptible areas, (2) establishment of new township schemes in relatively safer areas with earthquake-sustainable structural designs, and (3) extensive forestation for slope stability, erosion control, and provision of wood for flexible earthquake-resistant structures. The measures are needed for the sustainable development of the region. (Structural interpretation and geohazard assessment of a locking line: 2005 Kashmir earthquake, western Himalayas. Kausar, A.B. et al. (2015).

Digital elevation model (DEM) is remote sensing data which have been used to mapping and modelling of landslide hazard. Weighted overlay analysis is one of advance technique to analyses the various degree of landslide hazard based on deferent parameters and weightage assigned them, Bibi, T., Riaz,M. et al. (2016).

\section{Material and methods}

\subsection{Study area}

The entire Balakot Valley lies in the North of Mansehra District. Mansehra is located at the north eastern border of the Pukhtun Khawa province between $34^{\circ}-12^{\prime}$ to $35^{\circ}-50^{\prime} \mathrm{N}$ latitude and $47^{\circ}$ 07 ' to 74 to $08 \mathrm{E}$ longitudes. Mountain ranges, plains, valleys, numerous lakes and rivers are some of the main features of the geography of Mansehra. The topography of Balakot Valley is dominated by the high mountains, varying in elevation from of 2000 meters in the south to over 4500 meters above the sea level in the north. Mountains of great height occupy the northern part of the valley, and its adjacent areas in the west, north and east. In the north, along the boundary with Kohistan district, lies the great Himalaya Range. The famous Babusar Pass is situated in this range on the northeastern boundary of the Valley. The peak of famous Nanga Parbat is situated about 40 kilometers from the northeastern boundary of Balakot Valley.

\subsection{Work flow diagram}

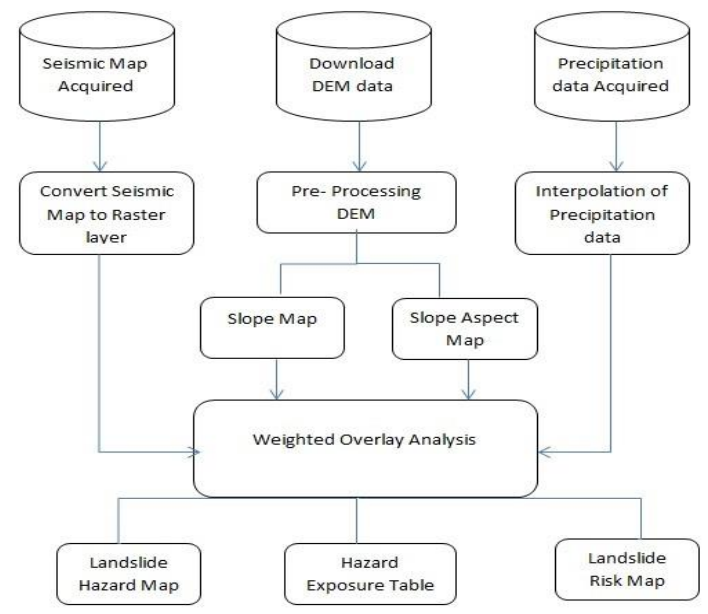

Fig. 1: Work flow diagram 


\subsection{Field data collection}

The primary data includes fieldwork carried out to collect spatial and non-spatial data through GPS surveys, field data collection, visits to different seasonal resorts in peak months, retrace and observe various features as required by the proposed research. Most of the secondary data was obtained from various sources including National Library of Earth Sciences, University of Peshawar, Geological Survey of Pakistan (Peshawar), Soil Survey of Pakistan (Peshawar), and C\&W Department Mansehra, Tourism department of Khyber Pakhtunkhwa, different websites and blogs. Maps include topographic maps and a guide map of the study area, District Census Report (DCR) was used for the bulk of information in the database. During the field work various tourist spots were visited, retraced and GPS coordinates were taken. GPS surveys were conducted to locate the tourist spots right from Balakot up to Jalkhad. Focus group discussions and questionnaire survey was also conducted while visiting these tourist points.

\subsection{Elevation data}

Aster 30 meter Elevation data was acquired from USGS website and clipped to area of interest to analyze landslide hazard zonation mapping. DEM were used to develop slope, aspect and contour generation, these raster layers was used to developed landslide hazard zonation, Blaschke, T et al (2013).

\subsection{Weighted Overlay Analysis}

Weighted overlay analysis was carried out on slope, slope aspect, seismic, land cover, Geology and precipitation data in arc GIS environment. The landslide hazard zonation map of Balakot was developed through weightage assigned and scaling of each to parameters (Slope, Slope Aspect, Geology, Land cover types, Seismic Maps, Precipitation Maps) as per their importance with respect to triggering of landslide in Balakot Valley.

Fig. 2: landslide Hazard Class Exposure

\section{Results and discussion}

In the present study, Landslide hazard zonation mapping were carried out using primary and secondary data in arc GIS environment. Tehsil Balakot was masked from the Khyber Pakhtunkhwa DEM through extract by mask tool of Spatial Data Analysis toolbox. The masked Tehsil DEM was further operated with fill tool from hydrology toolbox to clear the sinks and peaks. Elements are at risk to deferent risk class (high, medium and low). Tourist resorts and roads of Balakot tehsil are at risk of landslide hazard. Below graph describe about landslide hazard exposure of tensile Balakot. Total of 1016 sq. $\mathrm{km}$ of Balakot tehsil exposed to medium hazards class of landside, while 799 sq. km of Balakot tehsil are exposed to low hazard class and 499 sq. $\mathrm{km}$ are exposed to high hazards class of landslide respectively.

The digital slope model was extracted from the filled DEM of Tehsil Balakot through slope tool of spatial data analysis tool box. For each cell, the Slope tool calculates the maximum rate of change in value from that cell to its neighbours. Basically, the maximum change in elevation over the distance between the cell and its eight neighbours identifies the steepest downhill descent from the cell. The slope model represents five categories with different angles. The first level of the slope model ranges from 0 to 10 degree, and second level 10 to 20 . This slope is on the low and plain land and is often known as gentle to gentler slopes. These two categories are indicating safe sites from landslides triggering but in-fact these slopes indicate low lands which proves them as high velocity discharge of the catchments and flow accumulation possibly occur during the high rainy seasons. Mostly landslides also hit to these categories of slopes. 3rd, 4th and 5th indicate 20 to 30 degree, 30 to 40 degree and 40 to 76 degree slope respectively very prone to landslide hazards

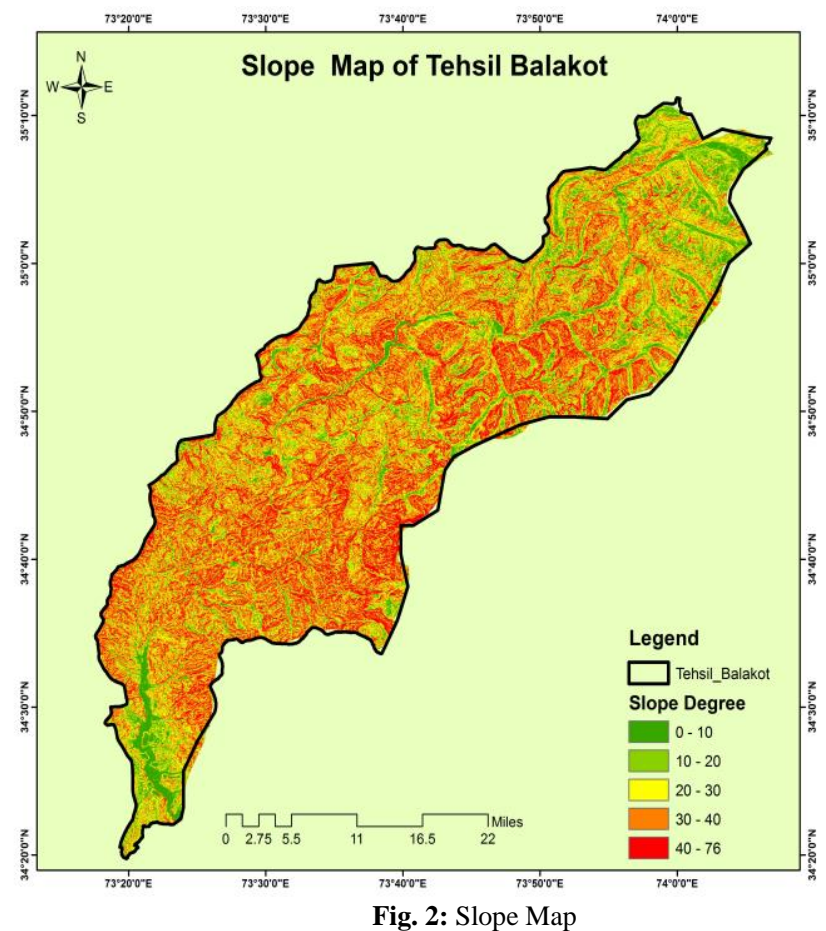

Annual precipitation trend is very high in Balakot due monsoon raining. In raining season Balakot has been hit by landslide hazard and flash flood. Overall lower Balakot received more rainfall than upper Balakot. Landslide hazard zonation map of Balakot show three main classes high, medium and low. Medium class Landslide hazards exposure more are than high and low.

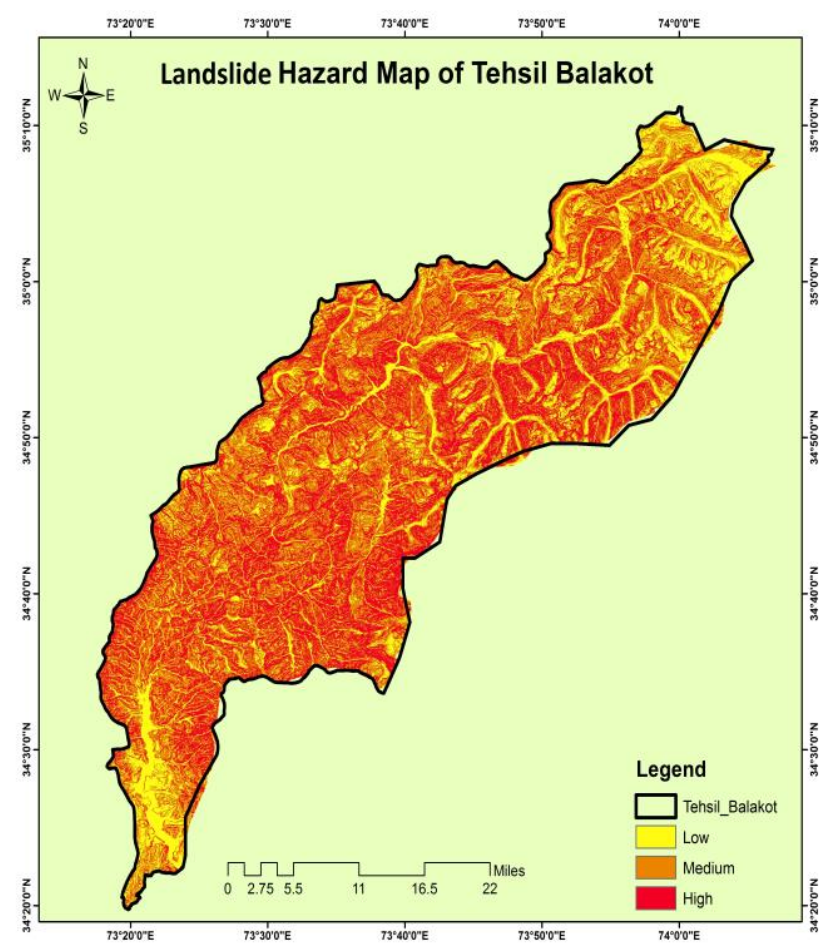

Fig. 3: Landslide Hazard Map

Elements are at risk to deferent risk class (high, medium and low). Tourist resorts and roads of Balakot tehsil are at risk of landslide hazard. Below graph describe about landslide hazard exposure of tensile Balakot. Total of $1016 \mathrm{sq}$. $\mathrm{km}$ of Balakot tehsil exposed to medium hazards class of landside, while 799 sq. km of Balakot tehsil are exposed to low hazard class and $499 \mathrm{sq} . \mathrm{km}$ are exposed to high hazards class of landslide respectively. 


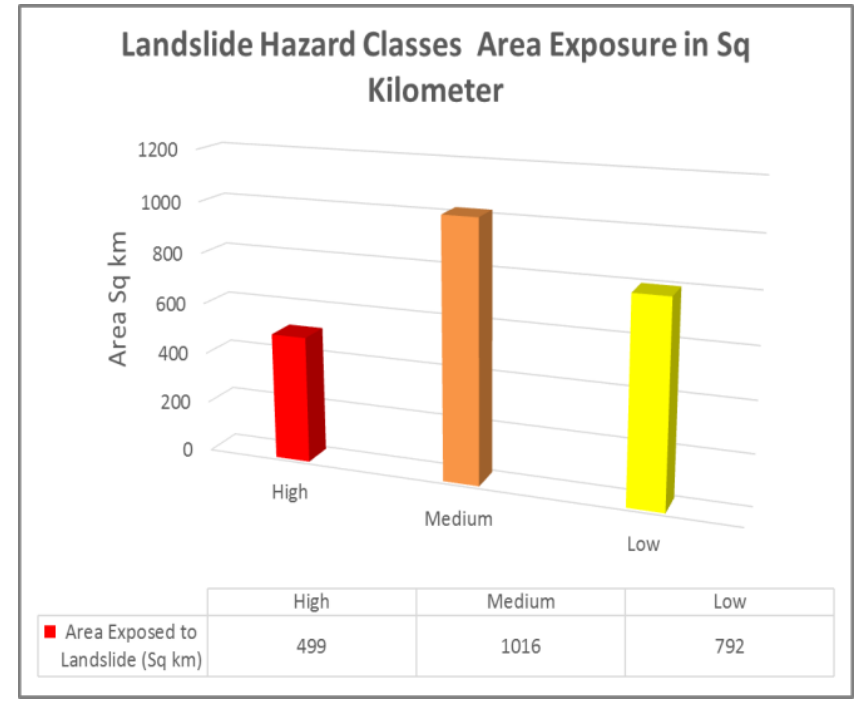

Graph 1: landslide Hazard Class Exposure

\subsection{Landslide impact on balakot valley}

In Balakot/ Kaghan valley, Landslides have caused major impacts on tourism, local habitants, their homes/possessions, and lifelines such as roads and communication system. Losses due to slope failures are great and apparently are growing as the fragile mountains receive additional pressure of precipitation mostly in monsoon season.

Various impacts of landslides have increased in past decades due to the rapid growth of tourist activities in Northern Pakistan. Landslide effects have damaged many aspects of human life and the natural environment, and many difficulties remain for accurate assessments and evaluations. Impacts of Landslides on tourism in Balakot valley are not yet studied as per requirement of the tourism department. Comprehensive view of landslide consequences on tourist activities is need of the time to cope with the serious threats and increasing damages and losses in Balakot valley. The lacks of systematic studies have resulted in a number of mishaps and even life losses along Balakot - Kaghan road. This paper attempts to describe a systematic organizational approach in framing landslide impacts in order to more reliably describe and integrate analysis and mitigation measures, Yalcin, A. et al. (2013).

Steep slopes, fragile land cover and strong earthquakes followed by heavy rains act together to create favourable conditions for landslide hazards in the Balakot valley. Landslides have caused major socioeconomic impacts on tourism in Balakot valley by effecting the homes, possessions and communications system of local people which ultimately affect the facilitations for the seasonal tourism. Socioeconomic losses due to slope failures are great and apparently are growing as the communication system is disturbed by the roadblocks under the pressure of increasing tourists visiting from all over the Pakistan. Being the only one rout to Naran Kaghan passing through Balakot city, possibility of blockade of main Balakot Kaghan road is much higher in mostly peak season of tourism, Torizin, J et al.

The lower proportion of ram lambs in Holla sheep compared to other locations in the mixed crop-livestock production system indicates the tradition of marketing young ram lambs because of the greater dependence on sheep production.

\subsection{Discussion}

In spite of the very evident importance of the Tourism Sector for Pakistan, the sector has not obtained its due attention from either the Federal or Provincial Governments. This fact is also substantiated by the report of World Travel and Tourism Competitiveness the Report; which ranked Pakistan 120 on the factor of Government prioritization of Travel \& Tourism (T\&T) Industry. In terms of T\&T enabling conditions, Pakistan was ranked 123rd.An inad- equate safety situation in the Balakot - Kaghan valley is the biggest challenge towards promoting tourism in this valley. Tourism is a cross cutting theme and is related to a number of other departments and ministries; such as environment, wild life, forestry, road and highways etc. However, all these ministries and departments keep working in isolation without taking into account the synergies which may be developed with Tourism. This results in missing out on many opportunities through which tourism development can take place without incurring much cost. Management of Tourism at the Provincial Level is carried out by Tourism Corporation of Khyber Pakhtunkhwa (TCKP). During field data collection and surveys it has been observed that the tourist mostly complain the role of TCKP staff in promotion of tourism in $\mathrm{Ka}$ ghan valley. There is no proper guidance for the tourists to keep them safe from the landslide prone areas in this valley.

Due to landslides and mass-movement activities, the Tourism Sector in Balakot valley and has suffered major losses, including physical damages to buildings, communication setup and equipment and lost businesses. This in turn has taken its toll on availability of tourist facilities in the valley. Damage caused to access roads, unreliable supply of electricity, poor sanitation at tourist spots, and lack of proper solid waste management has worsened the situation.TCKP through its website, have ensured its presence on the internet. However, this website failed to meet the needs of tourists. There are no facilities for getting online information on weather forecasts, road safety advices, prominent landslide spots, GIS Maps showing hazardous points/roadblocks etc. Most of these sites are developed in a routine manner and are of little use to the tourists. There is a need to provide a complete one-stop solution for the tourists. Following a stereotype approach limits the potential of information technology as a tool for tourism promotion. There is serious lack of an integrated approach for ensuring the supply of qualified human resource (managers and workers) for the Tourism Sector in Balakot -Kaghan valley. During road blocks and landslide activities, the negligence of the local and provincial tourism staff can be observed. During field visits, mostly tourists have identified the negative role of tourism staff during severe weather conditions. During questionnaire surveys, mostly tourists have identified the poor network facilities in severe weather conditions. It has been observed that during roadblocks due to heavy rain or snowfall mostly tourists fail to connect with their families on either side. There should be proper satellite communication system which cannot be interrupted during severe weather conditions. Mostly tourists have complains regarding the absence of Quick Response Teams at the roadblock sites due to landslide. In-case of any accident mostly tourists work at their own to cope with the sever events. There should be proper Quick Response Teams deputed at hazardous places to reach quickly for emergency situations.

Questionnaire surveys identified a severe price hike in hotel rooms booking, daily use items and petrol/diesel prices. It has been observed that on during landslides and road blocks, prices for every item are increased almost two hundred times. During a questionnaire survey, a tourist named Tajjamul from Lahore shared his experience of rising prices. He informed the author that, in August 2016 a landslide occurred in Kaghan valley and prices of Petrol were almost tripled due to shortage of fuel. Similarly price of every item was raised almost triple times. This is just because of the lack of proper check and control by district authorities.

\section{Conclusion and recommendation}

Landslide hazard zonation mapping using weighted overlay analysis is one of the advance techniques for mapping and modelling of landslide suitability in mountainous area of Balakot valley of $\mathrm{Pa}$ kistan. Primary data collect through field surveying and secondary data (precipitation, seismic and Digital elevation data were acquired from different source which have been used to develop landslide hazard and risk map of Balakot tehsil. The landslide zonation map has three hazards class high, Medium and low. The 
landslide exposure of high hazard class 499 sq.km while, Medium class 1016 sq.km and low hazard class having 749 sq. km exposure in balakot tehsil respectively. Exposure wise medium hazard type of landslide having high area coverage then, low hazard class and high hazard class. The tourism points, road infrastructures are directly to exposed to landslide hazard. This hazard exposure has become due random urbanization and unplanned road construction and deforestation. Landslides have caused major socioeconomic impacts on tourism in Balakot valley by affecting the homes, possessions and communications system of local people which ultimately affect the facilitations for the seasonal tourism. Socioeconomic losses due to slope failures are great and apparently are growing as the communication system is disturbed by the roadblocks under the pressure of increasing tourists visiting from all over the Pakistan. Landslide hazard zonation mapping using GIS and RS is the best way to assess the risk of landslide hazard in mountainous areas. The study recommended that ground penetrating radar (GPR) and soil testing based research well help to understand in-depth of landslide hazard condition in balakot valley.

\section{Acknowledgement}

T I feel highly privileged in taking opportunity to express my deepest gratitude and sincerest thanks to my respected Mr. Muhammad Dr. Naveed Tahir and all other authors and my Class fellows for his kind support from Geo information and earth observation (IGIEO) of PMAS Arid Agriculture University Rawalpindi.

\section{References}

[1] Ali, I., Shah, I., Hameed, A., Ashfaq, M., \& Muhammad, T. Archaeological Explorations In Balakot, District Mansehra

[2] Alimohammadlou, Y., Najafi, A., \& Yalcin, A. (2013). Landslide Process and Impacts: A Proposed Classification Method. Catena, 104, 219-232.

[3] Bibi, T., Gul, Y., Rahman, A. A., \& Riaz, M. (2016). Landslide Susceptibility Assessment through Fuzzy Logic Inference System (Flis). The International Archives of Photogrammetry, Remote Sensing and Spatial Information Sciences, 42, 355.

[4] Carrara, A., Cardinali, M., Detti, R., Guzzetti, F., Pasqui, V., \& Reichenbach, P. (1991). GIS techniques and statistical models in evaluating landslide hazard. Earth surface processes and landforms, 16(5), 427-445.

[5] Cater, C. I. (2006). Playing With Risk? Participant Perceptions of Risk and Management Implications in Adventure Tourism. Tourism Management, 27(2), 317-325.

[6] Drabek T.E. (1994). Risk Perceptions of Tourist Business Managers In: The Environmental Professional 16: S. 327ff.

[7] Feizizadeh, B., \& Blaschke, T. (2013). GIS-multicriteria decision analysis for landslide susceptibility mapping: comparing three methods for the Urmia lake basin, Iran. Natural hazards, 65(3), 21052128.

[8] Hungr, O., Leroueil, S., \& Picarelli, L. (2014). The Varnes classification of landslide types, an update. Landslides, 11(2), 167-194.

[9] Jadoon, I. A., Hinderer, M., Kausar, A. B., Qureshi, A. A., Baig, M. S., Basharat, M., \& Frisch, W. (2015). Structural interpretation and geo-hazard assessment of a locking line: 2005 Kashmir earthquake, western Himalayas. Environmental Earth Sciences, 73(11), 7587 7602 .

[10] Schickhoff, U. (1995). Himalayan forest-cover changes in historical perspective: A case study in the Kaghan valley, northern Pakistan. Mountain Research and Development, 3-18.

[11] Torizin, J., Fuchs, M., Awan, A. A., Ahmad, I., Akhtar, S. S., Sadiq, S.\& Sabir, F. Statistical landslide susceptibility assessment of the Mansehra and Torghar districts, Khyber Pakhtunkhwa Province, $\mathrm{Pa}$ kistan. Natural Hazards, 1-28.

[12] Xu, C., Xu, X., Yao, Q., \& Wang, Y. (2013). GIS-based bivariate statistical modelling for earthquake-triggered landslides susceptibility mapping related to the 2008 Wenchuan earthquake, China. Quarterly journal of engineering geology and hydrogeology, 46(2), 221-236. 